УДК 616.12-008.331.1-092:611-018.74:616.153.857

https://doi.org/10.30702/card:sp.2019.08.037/0260818

Молодан Д. В.

Харківський національний медичний університет, м. Харків, Україна

$\checkmark$ Molodan D. V.

Kharkiv National Medical University, Kharkiv, Ukraine

\title{
The level of Asymmetric Dimethylarginine and the State of Vascular Endothelium in Hypertensive Patients with Obesity and Hyperuricemia
}

\begin{abstract}
Asymmetric dimethylarginine is a new promising marker reflecting the state of vessels. The role of uric acid in the occurrence of cardiovascular diseases, despite the long history of its study, remains highly controversial. Numerous results of studies have proved the association of uric acid and cardiovascular diseases. At the same time, other studies involving large populations dismiss the presence of such a relationship.
\end{abstract}

Objective. To investigate the state of vascular endothelium in patients with asymptomatic hyperuricemia combined with obesity and hypertension. 
$\square$ Materials and methods. The study included 144 patients. The main group included 78 patients with stage 2, degree 2-3 hypertension combined with degree 2-3 obesity and asymptomatic hyperuricemia. The comparison group consisted of 46 patients with stage II, degree 2-3 hypertension combined with degree II-III obesity and normouricemia; the control group included 20 patients without any signs of pathology. The groups were gender- and age-matched.

Results. The level of asymmetric dimethylarginine was the highest in the group with asymptomatic hyperuricemia: $73(0.66 ; 0.82) \mu \mathrm{mol} / \mathrm{I}$ versus $0.65(0.53 ; 0.69) \mu \mathrm{mol} / \mathrm{l}$ in the group with normouricemia and $0.36 \mu \mathrm{mol} / /$ in the control group $(p<0.01)$. Endothelium-dependent vasodilation also worsened with the increase in the level of uricemia: its level was $12.04 \%$ in the control group, $5.9 \%(4.72 ; 7.05)$ in the group of patients with normouricemia, and $1.80 \%(1.25$; $2.96)$ in patients with hyperuricemia (p1-2,3<0.01). The measurements of microalbuminuria also showed a similar trend towards deterioration with uricemia increase: $8.93 \mathrm{mg} /$ day in the control group, $17.4(15.62 ; 8.45)$ in the normouricemia group, $28.1(19.09 ; 34.56)$ in the asymptomatic hyperuricemia group $(\mathrm{p} 1-2,3<0.01)$.

Conclusions. In hypertensive and obese patients with asymptomatic hyperuricemia, the indexes of the functional state of the endothelium were significantly worse compared to those with normal levels of uric acid and comparable body weight and blood pressure.

Keywords: hypertension, endothelial function, obesity, asymptomatic hyperuricemia, asymmetric dimethylarginine, endothelium-dependent vasodilation, microalbuminuria.

Резюме. Ендотелій є однією із ключових ланок регуляції діяльності судин. Його ушкодження передує розвитку численних патологічних станів, а порушена функція $\epsilon$ основою фрормування судинної патології. Визначення та дослідження механізмів ушкодження ендотелію $є$ важливим у запобіганні і лікуванні цілої низки захворювань. Найчастіше йдеться про гіпертонічну хворобу в поєднанні із метаболічними порушеннями, серед яких особливе місце займає безсимптомна гіперурикемія. Ї̈̈ роль у розвитку 
кардіоваскулярної патології, попри тривалу історію вивчення, залишається вкрай суперечливою. Існують численні спостереження про зв'язок такого стану з виникненням серцево-судинних захворювань. У літературі описані механізми, фрункціонуванням яких можна пояснити наявність зв'язку між рівнем сечової кислоти та пошкодженням судин [1]. Однак для остаточного встановлення ролі такого зв'язку необхідне проведення подальших досліджень.

У цьому контексті цікавим $є$ вивчення нових перспективних маркерів пошкодження судинної стінки, зокрема асиметричного диметиларгініну. Встановлено, що ця речовина зумовлює порушення роботи ендотеліальної синтази оксиду азоту, а також може розглядатись як прогностичний маркер виникнення серцево-судинних катастроф. Ураховуючи це, метою дослідження стало вивчення активності асиметричного диметиларгініну у хворих з поліморбідною патологією - гіпертонічною хворобою в поєднанні з ожирінням в умовах нормо- та гіперурикемії. Дослідження ендотелію проводили комплексно, з урахуванням стану ендотелій-залежної вазодилатації та динаміки мікроальбумінурії. Було встановлено, що розвиток гіпертонічної хвороби в поєднанні з ожирінням супроводжується достовірним підвищенням активності асиметричного диметиларгініну, зростанням мікроальбумінурії та зменшенням ендотелій-залежної вазодилатації. При цьому в групі осіб із безсимптомною гіперурикемією виявлено погіршення функціональних показників ендотелію порівняно 3 групою осіб, в яких відзначали нормоурикемію. Групи достовірно відрізнялися між собою. Дослідження кореляційних зв'язків між рівнями асиметричного диметиларгініну, мікроальбумінурії та змінами ендотелій-залежної вазодилатації засвідчило, що між цими показниками існує достовірний кореляційний зв'язок, який був сильніший із мікроальбумінурією. Можливо, це пов'язано із тим, що зміни рівня асиметричного диметиларгініну у крові і величина мікроальбумінурії певною мірою можуть залежати від фрункціонального стану нирок.

Ключові слова: гіпертонічна хвороба, функція ендотелію, ожиріння, безсимптомна гіперурикемія, асиметричний диметиларгінін, ендотелій-залежна вазодилатація, мікроальбумінурія. 